\title{
Pengaruh Keselamatan Dan Kesehatan Kerja Terhadap Kinerja Karyawan Pada PT. Kebun Pantai Raja
}

\author{
YAYU KUSDIANA \\ Sekolah Tinggi Ilmu Ekonomi Mahaputra Riau \\ Jalan Arifin Paus Pekanbaru \\ E-mail : yayu0677@gmail.com
}

\begin{abstract}
The purpose of this study was to determine the effect of occupational safety and health on employees' performance at PT. Kebun Pantai Raja (KPR) PKS - Tanjung Pauh Sengingi Hilir, Kuantan Sengingi. The method used in this research was quantitative descriptive method. The sample in this study were 58 people from 141 employees. The sample were taken by using random sampling (Random Sampling). The hypothesis in this study consist of $\mathrm{F}$ test, and $\mathrm{T}$ test. Based on $\mathrm{F}$ test result, it proved that safety and health has significantl effect to employee performance, indicated by value of Fcount which was bigger than Ftable $(31,061>3,165)$. Based on t test proved that the safety of work has significant effect to employees' performance which was shown by Tcount was bigger than Ttable $(4,187>2,003)$ and occupational health has significant effect to employees' performance at PT. Kebun Pantai Raja (KPR) PKS - Tanjung Pauh Sengingi Hilir- Kuantan Sengingi. It was shown by Tcount value was greater than Ttable $(4,224>2,003)$.
\end{abstract}

Keywords: Safety, Occupational Health, Performance

Upaya dalam mewujudkan tujuan perusahaan salah satunya adalah dengan mempunyai karyawan dengan kinerja yang baik. Kinerja karyawan merupakan hasil kerja yang dicapai oleh seorang karyawan dalam melaksanakan tugas yang diberikan kepadanya.

Karyawan merupakan kunci penentu keberhasilan perusahaan. Untuk itu setiap karyawan selain dituntut untuk memiliki pengetahuan, keterampilan, dan kemampuan, juga harus mempunyai pengalaman, motivasi, disiplin diri dan semangat kerja tinggi, sehingga jika kinerja karyawan perusahaan baik maka kinerja perusahaan juga akan meningkat yang menuju pada pencapaian tujuan perusahaan. Keberhasilan perusahaan dinilai dari suksesnya perusahaan dalam mencapai tujuan perusahaan.

Menurut Mangkunegara (2013), bahwa kinerja itu adalah hasil kerja secara kualitas dan kuantitas yang dicapai oleh seseorang karyawan dalam melaksanakan tugasnya sesuai dengan tanggung jawab yang diberikan kepadanya.
Sumber daya manusia yang berkualitas dan professional cenderung memiliki kinerja yang lebih baik, sehingga upaya peningkatan kualitas SDM sangat penting untuk diperhatikan oleh perusahaan. Keberhasilan perusahaan sangat erat kaitannya dengan kualitas kinerja karyawannya, sehingga perusahaan di tuntut tidak hanya memperhatikan kinerja kayawannya saja namun juga tingkat keselamatan dan kesehatan karyawan.

Sumber daya manusia sebagai tenaga kerja dalam perusahaan tidak terlepas dari adanya masalah yang berkaitan dengan Keselamatan dan Kesehatan Kerja (K3). Hal ini merujuk pada perlindungan tenaga kerja dari bahaya, penyakit dan kecelakaan akibat kerja maupun lingkungan kerja (Grahanintyas, dkk: 2012).

Bahaya kecelakaan akibat kerja yang menimpa para karyawan jika tidak dicegah dan ditanggulangi secara baik dan benar maka tentunya akan mengganggu jalannya perusahaan yang pada akhirnya akan berdampak buruk terhadap kinerja 
karyawan. Perusahaan perlu menerapkan program K3 (Keselamatan dan Kesehatan Kerja) untuk meningkatkan kinerja karyawan. Karena bila adanya jaminan tersebut maka karyawan akan lebih meningkatkan kinerjanya. Dengan program K3 yang baik, maka kecelakaan kerja dapat diminimalkan, yang pada akhirnya pengeluaran biaya dapat ditekan. Biaya yang dikeluarkan untuk keselamatan kerja dan kesehatan kerja cukup besar, terutama biaya tuntutan dari pihak - pihak yang tidak puas, termasuk dalam hal ini biaya untuk meningkatkan citra perusahaan yang terlanjur kurang baik akibat kelalaian kerja.

Perlindungan terhadap keselamatan dan kesehatan kerja karyawan diperusahaan dapat diwujudkan melalui pembinaan keselamatan dan kesehatan kerja agar tenaga kerja bisa terhindar dari resiko kecelakaan kerja, karena setiap tenaga berhak mendapatkan perlindungan atas keselamatan dan kesehatan kerjanya, seperti yang dinyatakan dalam pasal 86 Undang - Undang RI No. 13 tahun 2003 tentang ketenaga kerjaan.

Menurut Anwar (2012), dari hasil penelitiannya menyebutkan bahwa semakin tinggi perusahaan dalam memperhatikan keselamatan kerja karyawan maka akan meningkatkan kinerja karyawan.

Smith dan Sonesh

mengemukakan bahwa pelatihan kesehatan dan kelelamatan kerja (K3) mampu menurunkan resiko terjadinya kecelakaan kerja. Semakin besar pengetahuan karyawan akan K3 maka semakin kecil terjadinya resiko kecelakaan kerja, demikian sebaliknya semakin minimnya pengetahuan karyawan akan K3 maka semakin besar resiko terjadinya kecelakaan kerja

Sedangkan berdasarkan hasil penelitian yang dilakukan oleh Rahayu (2013), secara parsial program keselamatan kerja di lakukan oleh perusahaan terhadap karyawan memiliki pengaruh yang tidak signifikan terhadap kinerja karyawan.

Menurut para ahli Ratih (2017), Sari (2015) dan Rahyu (2013) mengatakan bahwa keselamatan dan kesehatan kinerja memiliki pengaruh namun tidak signifikan terhadap kinerja karyawan. Sedangkan menurut Sari (2016), Haerni, dkk (2014), Juwitasari, dkk (2014), Ilfani (2013), Putri (2013), Anwar (2012) dan Indriasari (2008) mengatakan bahwa keselamatan kerja berpengaruh positif dan signifikan terhadap kinerja karyawan .

Menurut Armstrong dan Baron, kinerja mempunyai makna lebih luas, bukan hanya menyatakan hasil kerja, tetapi juga bagaimana proses kerja berlangsung. Kinerja adalah tentang apa yang dikerjakan dan bagaimana cara mengerjakannya (Wibowo, 2011).

Menurut Mangkunegara (2013), bahwa kinerja itu adalah hasil kerja secara kualitas dan kuantitas yang dicapai oleh seseorang karyawan dalam melaksanakan tugasnya sesuai dengan tanggung jawab yang diberikan kepadanya.

Menurut Kasmir (2016), bahwa kinerja adalah hasil kerja dan perilaku kerja yang telah dicapai dalam menyelesaikan tugas - tugas dan tanggung jawab yang diberikan dalam suatu periode tertentu.

Moeheriono dalam Ma'ruf (2014), mengatakan bahwa kinerja karyawan mempunyai 6 indikator, yaitu: (1) Efektif; (2) Efesien; (3) Kualitas; (4) Ketepatan waktu; (5) Produktivitas;

Keselamatan dan kesehatan organisasi secara keseluruhan serta lingkungan kerja para karyawan ditinjau dari aspek kesehatan.

Widodo (2014), mengatakan
bahwa salah satu faktor yang mempengaruhi kinerja karyawan, sarana pendukung, yaitu hal yang berhubungan dengan lingkungan kerja (keselamatan kerja, kesehatan kerja, sarana produksi, dan teknologi) dan hal - hal yang berhubungan dengan kesejahteraan pegawai (upah/gaji, jaminan sosial, keamanan kerja).

Menurut Hendraman (2010), mengatakan bahwa keselamatan kerja adalah rangkaian usaha untuk

p.ISSN: $2407-800 X \quad$ e.ISSN: 2541-4356 
menciptakan suasana kerja yang aman dan tentram bagi karyawan yang bekerja diperusahaan yang bersangkutan.

Slamet (2012) dalam Widodo (2015), berpendapat bahwa keselamatan kerja dapat diartikan sebagai keadaan terhindar dari bahaya selama melakukan pekerjaan. Dengan kata lain keselamatan kerja merupakan salah satu faktor yang harus dilakukan selama bekerja.

Hal yang sama juga dikemukakan oleh Hartatik (2014), mengatakan bahwa keselamatan kerja adalah salah satu faktor yang harus dilakukan selama bekerja. Tidak ada seseorang pun didunia ini yang menginginkan terjadinya kecelakaan, keselamatan kerja sangat bergantung pada jenisnya, bentuk dan lingkungan dimana pekerjaan itu dilaksanakan.

Keselamatan kerja menyatakan bahwa sebagai keadaan terhindar dari bahaya selama melakukan pekerjaan dan salah satu faktor yang harus dilakukan selama bekerja. (Hartatik, 2014).

Pendapat tersebut juga di perkuat oleh Kasmir (2016), bahwa keselamatan kerja adalah aktivitas perlindungan karyawan yang secara menyeluruh. Artinya perusahaan berusaha untuk menjaga jangan sampai karyawan mendapatkan suatu kecelakaan pada saat menjalankan aktivitasnya.

Menurut Mengginson dalam Mangkunegara (2011) kesehatan kerja adalah suatu kondisi yang menunjukkan pada kondisi yang bebas dari gangguan fisik, mental, emosi atas rasa sakit yang disebabkan lingkungan kerja.

Pendapat tersebut dipertegas lagi oleh Kasmir (2016), dalam teorinya bahwa kesehatan kerja adalah upaya untuk menjaga agar karyawan tetap sehat selama bekerja. Artinya, jangan sampai kondisi lingkungan kerja akan membuat karyawan tidak sehat.

Karyawan harus bisa menjaga kesehatan baik secara jasmani, rohani, maupun sosial agar pekerjaan yang diberikan oleh perusahaan dapat dikerjakan dengan baik. Dengan adanya usaha pencegahan dan pengobatan terhadap penyakit, karyawan akan merasa baik dalam melakukan pekerjaannya.

Untuk terhindarnya dari bahaya akibat kerja karyawan ataupun masyarakat yang lainnya harus bisa menjaga kesehatan sebaik mungkin agat tidak adanya gangguan pada aktifitas dalam melakukan pekerjaan.

Menurut Soedirman dan Sama'mur (2014), berpendapat bahwa kesehatan kerja adalah bagian dari ilmu kesehatan secara praktiknya dalam pemeliharaan kesehatan secara kuratip, proventif, promosional, dan rehabilitive agar masyarakat tenaga kerja dan masyarakat umum terhindar dari bahaya akibat kerja, serta dapat memperoleh derajat kesehatan setinggi - tingginya untuk dapat bekerja dengan baik.

Kesehatan kerja merupakan suatu kondisi kesehatan yang bertujuan agar pekerja memperoleh derajat kesehatan setinggi - tingginya, baik jasmani, rohani, maupun sosial, dengan usaha pencegahan dan pengobatan terhadap penyakit atau gangguan kesehatan yang disebabkan oleh pekerjaan dan lingkungan kerja maupun penyakit umum (Hartatik, 2014).

Menurut Kasmir (2016), tujuan dari keselamatan kerja dan kesehatan kerja adalah sebagai berikut ini: (1) Membuat karyawan merasa nyaman; (2) Memperlancar proses kerja; (3) Agar karyawan berhati - hati dalam bekerja; (4) Mematuhi aturan dan rambu - rambu kerja; (5) Tidak mengganggu proses kerja.

Menurut Satria dalam Widodo (2015), mengatakan bahwa tujuan dari keselamatan dan kesehatan kerja adalah: (1) Melindungi para pekerja dan orang lain ditempat kerja; (2) Menjamin agar disetiap sumber produksi dapat dipakai secara aman dan efesien; (3) Menjamin proses produksi berjalan dengan lancar.

Menurut Mangkunegara (2013), mengatakan bahwa tujuan dari keselamatan dan kesehatan kerja adalah sebagai berikut ini: (1) Agar setiap pegawai mendapat jaminan keselamatan 
dan kesehatan kerja baik secara fisik, sosial, dan psikologis; (2) Agar setiap perlengkapan dan peralatan kerja digunakan sebaik - baiknya, seefektif mungkin; (3) Agar semua hasil produksi dipelihara keamanannya; (4) Agar adanya jaminan atas pemeliharaan dan peningkatan kesehatan gizi karyawan; (5) Agar meningkat kegairahan, keserasian kerja, dan partisipasi kerja; (6) Agar terhindar dari gangguan kesehatan yang disebabkan oleh lingkungan kerja atau kondisi kerja; (7) Agar setiap karyawan merasa aman dan terlindungi dalam bekerja.

Menurut Widodo (2015), dsalam rangka peningkatan keselamatan kerja dan kesehatan kerja perlu dibuat suatu program sebagai berikut ini: (1) Libatkan manajemen dan karyawan dalam menyusun program keselamatan kerja dan kesehatan kerja; (2) Tentukan siapa yang betanggung jawab dalam melaksanakan program kerja; (3) Tentukan kebutuhan keselamatan kerja dan kesehatan kerja yang dibutuhkan pada bagian masing - masing; (4) Ketahui bagian mana dari fasilitas perusahaan yang membahayakan; (5) Perbaiki bagian bagian yang berbahaya; (6) Latih karyawan dalam teknik keselamatan kerja dan kesehatan kerja; (7) Ciptakan suatu mind set para karyawan bahwa peruasahaan harus bebas dari potensi bahaya; (8) Secara terus menerus perbaiki dan sempurnakan program keselamatan kerja dan keseahatan kerja yang ada.

Menurut Hartatik (2014), upaya untuk meningkatkan keselamatan dan kesehatan kerja bisa dilakukan sebagai berikut ini: (1) Mencegah dan mengurangi kecelakaan; (2) Mencegah, mengurangi, dan memadamkan kebakaran;

Mencegah dan mengurangi bahaya peledakan; (4) Memberikan kesempatan menyelamatkan diri pada waktu kebakaran atau kejadian - kejadian lain yang berbahaya; (5) Memberikan pertolongan pada kecelakaan; (6) Memberikan alat alat pelindung diri pada para pekerja; (7) Memperoleh penerangan yang cukup dan

Jurnal Daya Saing (Vol. 4, No. 2 Jun 2018) sesuai; (8) Memelihara kebersihan, kesehatan, dan ketertiban.

Menurut Kusdyah (2008), usaha untuk meningkatkan keselamatan dan kesehatan kerja bisa dilakukan adalah: (1) Pemeriksa kesehatan sebelum bekerja; (2) Pemeriksaan kesehatan berkala untuk evaluasi; (3) Pendidikan tentang kesehatan dan keselamatan kerja karyawan secara kontiniu; (4) Penerangan dan penjelasan sebelum bekerja; (5) Pakaian pelindung misalnya masker, kacamata, sarung tangan, sepatu, topi pakaian kerja, dan sebagainya; (6) Isolasi yaitu mengisolasi operasi atau proses produksi dalam memperoleh yang membahayakan karyawan, misalnya mengisolasi mesin yang sangat berisik agar tidak menjadi mengaggu kinerja pekerja lainnya; (7) Ventilasi setempat ialah alat untuk menghisap udara disuatu tempat kerja tertentu, agar bahan - bahan dari suatu tempat dihisap dan dialirkan keluar; (8) Substitusi, yaitu mengganti bahan yang lebih bahaya dangan bahan yang kurang bahaya sama sekali, misalnya Carbontetrachorida diganti dengan trichlor etilen.

\section{METODE}

Penelitian ini dilakukan di PT. Kebun Pantai Raja (KPR) PKS - Tanjung Pauh Kec. Sengingi Hilir Kab. Kuantan Sengingi Provinsi Riau.

Populasi dalam penelitian ini adalah semua karyawan pada PT. Kebun Pantai Raja (KPR) PKS - Tanjung Pauh yang berjumlah 141 orang. Sedangkan sampel yang digunakan dalam penelitian ini menggunakan sampel secara acak (Random Sampling) dengan menggunakan rumus Yamane atau sebanyak 51 orang.

Metode pengumpulan data melalui kuesioner dan wawancara langsung pada pimpinan perusahaan tentang berbagai informasi/data yang diperlukan.

Kuesioner adalah daftar pertanyaan yang disebarkan kepada seluruh karyawan pada PT. Kebun Pantai Raja (KPR) PKS p.ISSN: 2407-800X e.ISSN: 2541-4356 
Tanjung Pauh Kec. Sengingi Hilir Kab. Kuantan Sengingi. Untuk mengetahui tingkat kinerja karyawan, keselamatan kerja dan kesehatan kerja dengan menggunakan skala likert. Skala likert digunakan untuk mengukur sikap, pendapat dan persepsi seseorang atau sekelompok orang tentang fenomenal sosial. Dengan skala likert, maka variabel yang diukur dan dijabarkan menjadi indikator variabel.

Kemudian indikator tersebut dijadikan sebagai titik tolak untuk menyusun item item instrument yang dapat berupa pernyataan dan pertanyaan. Jawaban setiap item yang menggunakan skala likert mempunyai gradiasi dan sangat positif sampai sangat negatif (Sugiyono, 2010).

Analisis deskriptif digunakan untuk menggambarkan tentang ringkasan variabelvariabel penelitian tanpa mengkaitkan atau membandingkan dengan variabel yang lainnya. Jadi menjelaskan karakterisitk statistik suatu variabel secara mandiri.

Statistik inferensial sering juga disebut statistik induktif atau statistik probalititas, adalah teknik statistik yang digunakan untuk menganalisis data sampel dan hasilnya diberlakukan untuk populasi.

Analisis linear regresi berganda adalah hubungan secara linear antara dua atau lebih variabel bebas Keselamatan $\left(\mathrm{X}_{1}\right)$ dan Kesehatan $\left(\mathrm{X}_{2}\right)$ dengan variabel terikat Kinerja Karyawan (Y). Model regresi berganda dikembangkan untuk melakukan estimesi/prediksi nilai variabel dependen (Y) dengan menggunakan lebih dari satu variabel indenpenden $\left(\mathrm{X}_{1}, \mathrm{X}_{2}, \mathrm{X}_{3}, \mathrm{dst}\right)$. Persamaan regresi linear berganda adalah :

\section{$\mathbf{Y}=\mathbf{a}+\mathbf{b}_{1} \mathbf{X}_{1}+\mathbf{b}_{2} \mathbf{X}_{2}+\mathbf{e}$}

Keterangan :

$\begin{array}{ll}\mathrm{Y} & =\text { Variabel terikat (Kinerja) } \\ \mathrm{a} & =\text { Konstanta } \\ \mathrm{b}_{1} \mathrm{~b}_{2} & =\text { Koefisien Berganda } \\ \mathrm{e} & =\text { Error } \\ \mathrm{X}_{1} & =\text { Keselamatan } \\ \mathrm{X}_{2} & =\text { Kesehatan }\end{array}$

\section{HASIL}

Rekapitulasi tanggapan responden terhadap keselamatan kerja $\left(\mathrm{X}_{1}\right)$ dengan jawaban sangat setuju sebanyak 130 responden dengan bobot 650 , jawaban untuk setuju sebanyak 115 responden dengan bobot 460, sedangkan jawaban untuk netral sebanyak 124 responden dengan bobot 372 , jawaban untuk tidak setuju sebanyak 134 responden dengan bobot 268, dan sangat tidak setuju menjawab sebanyak 19 responden dengan bobot 19. Maka dapat disimpulkan bahwa rata - rata jawaban responden adalah sebesar 3,38. Ini termasuk dalam kategori setuju bahwa faktor lingkungan, faktor manusia, dan faktor alat berpengaruh terhadap keselamatan kerja mereka. rekapitulasi tanggapan responden terhadap kesehatan kerja $\left(\mathrm{X}_{2}\right)$ dengan jawaban sangat setuju sebanyak 159 responden dengan bobot 795 , jawaban untuk setuju sebanyak 125 responden dengan bobot 500, sedangkan jawaban untuk netral sebanyak 159 responden dengan bobot 477, jawaban untuk tidak setuju sebanyak 69 responden dengan bobot 138, dan sangat tidak setuju menjawab sebanyak 10 responden dengan bobot 10 . Maka dapat disimpulkan bahwa rata - rata jawaban responden adalah sebesar 3,68. Ini termasuk dalam kategori setuju bahwa lingkungan kerja secara medis, sarana kesehatan tenaga kerja, dan pemeliharaan kesehatan berpengaruh terhadap keselamatan kerja mereka.

Dari rekapitulasi tanggapan responden terhadap kinerja $(\mathrm{Y})$ pada tabel 3, jawaban sangat setuju sebanyak 216 dengan bobot 1080, jawaban untuk setuju 210 dengan bobot 840, jawaban untuk netral 203 dengan bobot 609, jawaban untuk tidak setuju 50 dengan bobot 100 , dan jawaban untuk sangat tidak setuju 16 dengan bobot 16. Maka dapat disimpulkan bahwa rata - rata jawaban responden adalah sebesar 3,80. Ini termasuk kedalam kategori setuju bahwa kualitas, kuantitas, pelaksanaan tugas, dan tanggung jawab berpengaruh terhadap kinerja. 
Berdasarkan tabel 4, maka persamaan regresi sebagai berikut:

$$
\begin{aligned}
& Y=a+b_{1} x_{1}+b_{2} x_{2}+e \\
& Y=12,387+0,504 x_{1}+0,538 x_{2}+e \\
& \text { Analisisnya: }
\end{aligned}
$$

a. Konstanta (a) bernilai 12,387 jika variabel keselamatan dan kesehatan kerja sama dengan nol, maka kinerja karyawan (Y) diperoleh 12,387.

b. Nilai koefisien regresi dari variabel keselamatan $\left(\mathrm{X}_{1}\right)$ sebesar 0,504 artinya jika variabel kinerja karyawan naik 1 satuan maka variabel kinerja karyawan akan mengalami kenaikan 0,504 .

c. Nilai koefisien regresi dari kesehatan kerja $\left(\mathrm{X}_{2}\right)$ sebesar 0,538 artinya jika variabel kinerja karyawan naik 1 satuan maka variabel kinerja karyawan akan mengalami kenaikan 0,538 .

Nilai K-S-Z untuk variabel keselamatan kerja adalah sebesar 0,475 dengan signifikansi sebesar 0,978. Nilai K-S$\mathrm{Z}$ untuk variabel kesehatan kerja adalah sebesar 0,721 dengan signifikansi sebesar 0,676 . Nilai K-S-Z untuk variabel kinerja adalah sebesar 0,691 dengan signifikansi 0,726 . Nilai $\mathrm{K}-\mathrm{S}-\mathrm{Z}$ semua variabel tersebut diatas 0,05, maka dapat diambil kesimpulan bahwa semua variabel secara statistik telah berdistribusi secara normal dan layak digunakan sebagai data penelitian.

Bahwa masing - masing nilai $t_{\text {hitung }}$ dan signifikan variabel bebas, diketahui nilai $\mathrm{t}_{\text {tabel }}$ dengan persamaan $\mathrm{n}-\mathrm{k}=58-2=56$, alpha $/ 2=0,05 / 2=0,0025=2,003$, pada taraf signifikan $5 \%$ dengan demikian diperoleh sebagai berikut ini :

1) Keselamatan Kerja $\left(X_{1}\right)$

Diketahui $t_{\text {hitung }}(4,187)>t_{\text {tabel }}(2,003)$ dengan signifikan $(0,000)<(0,005)$ artinya variabel keselamatan kerja berpengaruh signifikan terhadap kinerja karyawan.

2) Kesehatan Kerja $\left(X_{2}\right)$

Diketahui $t_{\text {hitung }}(4,224)>t_{\text {tabel }}(2,003)$ dengan signifikan $(0,000)<(0,005)$ artinya variabel kesehatan kerja berpengaruh signifikan terhadap kinerja karyawan.

Dari perhitungan bahwa hasil $\mathrm{f}_{\text {hitung }}$ sebesar 31,061 dengan signifikan 0,000. $\mathrm{f}_{\text {tabel }}$ dengan persamaan $\mathrm{n}-1=58-2-1=$ $55=3,165, f_{\text {tabel }}$ pada signifikan $5 \%$. Dengan demikian diketahui $\mathrm{f}_{\text {hitung }}=31,061$ $>\mathrm{f}_{\text {tabel }}=3,165$ dengan signifikan $(0,000)<$ $(0,005)$ maka $\mathrm{H}_{0}$ ditolak atau signifikan. Ini berarti secara bersama - sama keselamatan dan kesehatan kerja berpengaruh secara signifikan terhadap kinerja karyawan.

Perhitungan nilai koefesien determinasi (Ajust $R$ Square) diperoleh nilai sebesar 0,513. Hal ini menunjukkan bahwa keselamatan dan kesehatan kerja memberikan pengaruh sebesar 51,3\% terhadap kinerja karyawan PT. Kebun Pantai Raja (KPR) PKS - Tanjung Pauh Kec. Sengingi Hilir Kab. Kuantan Sengingi. Sisanya $48,7 \%$ merupakan variabel lain yang tidak termasuk dalam penelitian.

\section{PEMBAHASAN}

Variabel keselamatan dan kesehatan kerja berpengaruh signifikan terhadap kinerja karyawan pada PT. Kebun Pantai Raja (KPR) PKS - Tanjung Pauh Kec. Sengingi Hilir Kab. Kuantan Sengingi. Hasil regresi secara parsial variabel keselamatan kerja $t_{\text {hitung }}$ sebesar $(4,187)>$ $t_{\text {tabel }}$ sebesar $(2,003)$. Dengan begitu faktor keselamatan kerja secara signifikan mempengaruhi kinerja karyawan pada PT. Kebun Pantai Raja (KPR) PKS - Tanjung Pauh Kec. Sengingi Hilir Kab. Kuantan Sengingi. Dan variabel kesehatan kerja $t_{\text {hitung }}(4,224)>t_{\text {tabel }}$ sebesar $(2,003)$. Dengan begitu faktor kesehatan kerja secara signifikan mempengaruhi kinerja karyawan pada PT. Kebun Pantai Raja (KPR) PKS Tanjung Pauh Kec. Sengingi Hilir Kab. Kuantan Sengingi.

Hasil regresi secara simultan semua variabel $f_{\text {tabel }}$ sebesar $(31,061)>f_{\text {hitung }}$ sebesar $(3,165)$ maka hipotesis nol $\left(\mathrm{H}_{\mathrm{a}}\right)$ diterima atau signifikan. Dengan demikian dapat disimpulkan bahwa secara bersama sama faktor keselamatan dan kesehatan kerja mempengaruhi kinerja karyawan pada PT. Kebun Pantai Raja (KPR) PKS Tanjung Pauh Kec. Sengingi Hilir Kab. Kuantan Sengingi.

p.ISSN: 2407-800X e.ISSN: 2541-4356 
$\underset{\text { Berdasarkan }}{\stackrel{2}{2} \text { tabel koefisien }}$ pengaruh variabel $\left(X_{1}\right.$ dan $\left.X_{2}\right)$ berpengaruh terhadap variabel terikat (Y). Dari hasil penelitian dapat dilihat bahwa nilai Adjusted R Square sebesar 0,513 atau 51,3\% berarti keselamatan dan kesehatan kerja berpengaruh signifikan terhadap kinerja karyawan pada PT. Kebun Pantai Raja (KPR) PKS - Tanjung Pauh Kec. Sengingi Hilir Kab. Kuantan Sengingi, sedangkan sisanya $48,7 \%$ dipengaruhi oleh faktor yang tidak diteliti dalam penelitian ini.

Diharapkan pihak perusahaan lebih memperhatikan, memperbaiki dan melengkapi penyusunan lay out mesin, fasilitas dan suasana kerja, dan peralatan kerja agar keselamatan kerja lebih terjaga. Diharapkan pihak perusahaan memperhatikan, memberikan dan melengkapi alat - alat kesehatan, melakukan pemeriksaan kesehatan dan jaminan kesehatan agar para karyawan merasa lebih terjamin kesehatannya dalam bekerja. Semua pihak yang terlibat dalam oerasional perusahaan selalu mengutamakan dan memprioritaskan Keselamatan dan Kesehatan Kerja (K3).

\section{SIMPULAN}

Terbukti bahwa keselamatan kerja berpengaruh signifikan terhadap kinerja karyawan ditunjukkan dengan nilai $t_{\text {hitung }}$ lebih besar dari $t_{\text {tabel }}(4,187>2,003)$ dan kesehatan kerja berpengaruh signifikan terhadap kinerja karyawan pada PT. Kebun Pantai Raja (KPR) PKS - Tanjung Pauh Kec. Sengingi Hilir Kab. Kuantan Sengingi ditunjukkan dengan nilai $t_{\text {hitung }}$ lebih besar dari $t_{\text {tabel }}(4,224>2,003)$.

\section{DAFTAR RUJUKAN}

Grahanintyas, Dewinta, Sritomo Wignjosoebroto dan Effi Latiffianti. 2012. Analisa Keselamatan dan Kesehatan Kerja (K3) Dalam Meningkatkan Produktivitas (Studi Kasus: Pabrik The Wonosari PTPN
XII). Jurnal Teknik omits. Vol. 1, No. 1. 2012. 1 - 6 .

Hartatik, Puji Indah. 2014. Mengembangkan Sumber Daya Manusia. Jakarta: Laksana.

Hearni, Rizkya, Kusdi Raharjo dan Gunawan Eko Nurtjahjono 2014. Pengaruh Keselamatan dan Kesehatan Kerja Terhadap Kinerja Karyawan Tetap PT. Perkebunan Nusantara X (Persero) Pabrik Gula Toelangan Sidoarjo. Jurnal Administrasi Bisnis. Volume 15. Nomor. 1. Oktober 2014.

Hendraman. 2010. Penyakit Akibat Kerja dan Penyakit Akibat Hubungan Kerja Ditempat Kesehatan Kerja. http://www.infokeselamatankerja. wordpress.com.

Ilfani, Grisma. 2013. Analisis Pengaruh Keselamatan dan Kesehatan Kerja Terhadap Kinerja Karyawan (Studi pada PT. Apac Inti Corpora Bawen Jawa Tengah Spinning 2). Skripsi. Fakultas Ekonomi dan Bisnis Universitas Diponegoro Semarang.

Indriasari, Nia. 2008. Pengaruh Keselamatan dan Kesehatan Kerja Terhadap Kinerja Karyawan (Studi pada Karyawan Bagian Produksi PT. Surabaya Agung Industri Pulp dan Kertas). Skripsi. Fakultas Ilmu Administrasi Jurusan Administrasi Niaga Konsentrasi Manajemen Sumber Daya Manusia Universitas Brawijaya Malang.

Juwitasar, Veronica Muqista Aji, Muchammad Al Musadieq dan Arik Prasetya, 2014. Pengaruh Keselamatan dan Kesehatan Kerja Terhadap Kinerja Karyawan (Studi

p.ISSN: 2407-800X e.ISSN: 2541-4356 
pada Karyawan Produksi PT. Inti Luhur Fuja Abadi, Baji Pasuruan. Jurnal Administrasi Bisnis. Volume 5. Nomor 2. Oktober 2014.

Kasmir. 2016. Manajemen Sumber Daya Manusia (Teori dan Praktik). Jakarta: RajaGrafindo Persada.

Kartikasari, Ratih Dwi 2017. Pengaruh Keselamatan dan Kesehatan Kerja Terhadap Kinerja Karyawan (Studi pada Karyawan Bagian Produksi PT. Surya Asbes Cement Group Malang. Skripsi. Fakultas Ilmu Administrasi Universitas Brawijaya Malang.

Kusdyah, Ike Rachmawati. 2008. Manajemen Sumber Daya Manusia. Yogyakarta : Andi.

Ma'ruf, Abdullah. 2014. Manajemen dan Evaluasi Kinerja Karyawan. Yogyakarta: Aswaja Presindo.

Mahendra, Rahman. 2009. Hubungan Jaminan Keselamatan dan Kesehatan Kerja dengan Motivasi Kerja (Survey pada Karyawan bagian Produksi PT. Bentor Prima Malang. Skripsi. Fakultas Ilmu Administrasi. Malang. Universitas Brawijaya.

Mangkunegara, Anwar Prabu. 2013. Manajemen Sumber Daya Manusia Perusahaan. Bandung : PT. Remaja Rosdakarya.

Mangkunegara, Anwar Prabu. 2011. Manajemen Sumber Daya Manusia Perusahaan. Bandung : PT. Remaja Rosdakarya.

Putri, Rozi Anggela 2015. Pengaruh Keselamatan dan Kesehatan Kerja Terhadap Kinerja Karyawan pada PT. Bridgestone Tire Indonesia, Bekasi Plant. Skripsi. Fakultas
Ekonomi Universitas Darma Persada Jakarta.

Rahayu, Ira Wati, 2013. Pengaruh Keselamatan dan Kesehatan Kerja Terhadap Kinerja Karyawan pada PT. Indonesia Asahan Alumunium (INALUM), Kuala Tanjung. Skripsi. Fakultas Ekonomi Universitas Sumatera Utara Medan.

Rizky, Murody Anwar, 2012. Pengaruh Kesehatan dan Keselamatan Kerja Terhadap Kinerja Karyawan pada PT. Kusuma Dipa Nugraha Mojokerto. Skripsi. Fakultas Ekonomi Pembangunan Nasional Veteran Jawa Timur.

Sari, Adyasti Andika. 2016. Pengaruh Keselamatan dan Kesehatan Kerja Terhadap Kinerja Karyawan (Studi pada PT. Guna Mekar Industri, Semarang). Skripsi. Fakultas Sains dan Teknologi Universitas Islam Negeri Sunan Kalijaga Yogyakarta.

Sedarmayanti. 2009. Sumber Daya Manusia dan Produktivitas Kerja. Yogyakarta : Pustaka Belajar.

Smith, A., and Sonesh, S. 2011, How Hazards and safety Trainning Influence Learning and Performance. Journal of Alied Psychology. 2011. American Psycological Association. Vol. 96. No. 1.46 - 700021 9010/11/\$12.00 DOI: 10.1037/a0021838, Tulane University, Amerika.

Soedirman dan Sama'mur. 2014. Kesehatan Kerja Dalam Perspektif Hiperkers dan Keselamatan Kerja. Jakarta : Erlangga 
Sugiyono. 2014. Metode Penelitian Bisnis. ALFABETA

Rizky, Murody Anwar, 2012. Pengaruh Kesehatan dan Keselamatan Kerja Terhadap Kinerja Karyawan pada PT. Kusuma Dipa Nugraha Mojokerto. Skripsi. Fakultas Ekonomi Pembangunan Nasional Veteran Jawa Timur.

Sari, Putri Lutfi Anjar 2015. Pengaruh Keselamatan dan Kesehatan Kerja Terhadap Kinerja Karyawan pada PT. Bridgestone Tire Indonesia, Bekasi Plant. Skripsi. Fakultas Ekonomi Universitas Darma Persada Jakarta.

Wibowo, 2011. Manajemen Kinerja, Jakarta: Rajawali Pers.

Widodo, Eko Suparno. 2015. Manajemen Pengembangan Sumber Daya Manusia. Yogyakarta : Pustaka Belajar. 